\title{
La prohibición de ir contra acto propio en la justicia civil chilena
}

\author{
Jorge Larroucau Torres*
}

\begin{abstract}
RESUMEN
La probibición de ir contra acto propio es un escenario típico de infracción a la buena fe procesal, cuyo contenido y límites la ley chilena no ha definido. Este artículo analiza las dos interpretaciones -una amplia y otra restringida-que cobija la jurisprudencia civil respecto de este deber de coherencia y la manera en que ellas inciden en el derecho de defensa de las partes. El texto distingue entre una aplicación secundaria (obiter dicta) y una aplicación residual de este deber, siendo esta última un control judicial de la argumentación jurídica del litigante ante situaciones de abuso, engaño y actuaciones manifiestamente dilatorias. El efecto procesal de infringir este deber es la inadmisibilidad del acto incoherente. Este efecto es compatible con otras medidas específicas, como el pago de las costas y la indemnización de los daños causados.
\end{abstract}

Acto propio; buena fe procesal; derecho de defensa

\section{The doctrine of estoppel in Chilean civil justice}

\begin{abstract}
The doctrine of estoppel is a typical scenario of violation of the procedural good faith which content and limits have not been defined by the Chilean law yet. This paper analyzes both interpretations -a broad one and a narrow one-containing the civil jurisprudence regarding this duty of consistency and the way in which they affect the right to defense of the parties. The paper distinguishes between a secondary application (obiter dicta) and a residual application of this duty, the latter being a judicial control of the litigant's legal arguments in situations of abuse, deception and manifestly dilatory strategies. The procedural effect of infringing this duty is the inadmissibility of the inconsistent action. This effect is consistent with other specific measures such as the payment of costs and the compensation for damage caused.
\end{abstract}

Doctrine of estoppel; procedural good faith; right to defence

* Licenciado en Ciencias Jurídicas y Sociales, Universidad de Concepción, Chile. Doctor en Derecho, Universidad de Chile. Profesor de Derecho Procesal Civil, Pontificia Universidad Católica de Valparaíso, Chile. Correo electrónico: jorge.larroucau@pucv.cl.

Este artículo es parte de una investigación financiada mediante un proyecto Fondecyt Regular ( $\mathrm{N}^{\circ}$ 1170067: "El principio de la buena fe procesal. Análisis dogmático y crítico de su rol como fuente de cargas, deberes y sanciones en la formación del debate”, 2017-2018) cuyo apoyo agradezco. También debo agradecer a Belén Carrión Griffiths y Pablo Cantillana Guerrero, ayudantes de Derecho Procesal Civil de la Pontificia Universidad Católica de Valparaíso, por su exhaustiva búsqueda de los fallos que se citan en este trabajo.

Artículo recibido el 3.1.2019 y aceptado para su publicación el 3.9.2019. 


\section{INTRODUCCIÓN}

E ste artículo analiza la prohibición de ir contra acto propio como un escenario típico de infracción al principio de buena fe procesal que rige en los procedimientos judiciales en Chile ${ }^{1}$. Esta prohibición se traduce en un deber de coherencia que incluye tanto acciones como omisiones, las que pueden tener lugar con anterioridad al juicio o durante el transcurso del mismo, sin distinguir entre tipos de litigantes, ni la posición que ellos ocupan en el juicio, sea como demandante o demandado. Por esta razón, se trata de un deber procesal que alcanza incluso a quienes litigan al alero de derechos irrenunciables, como es el caso de los consumidores y los trabajadores ${ }^{2}$.

La amplitud de esta prohibición ha generado múltiples debates que es preciso abordar. Por ejemplo, en Olguín con Vega la Corte Suprema confirmó la decisión que rechazó el argumento con el que la demandada se opuso a un divorcio unilateral por cese de la convivencia -arguyendo que el actor había incumplido su obligación de alimentos-, ya que durante casi treinta años la demandada no había reclamado dichos alimentos, de modo que para la Corte Suprema resultaba "sorprendente" que pretendiera hacerlo para enervar la acción ${ }^{3}$.

¿Significa esto que un litigante no puede adoptar ningún curso de acción que difiera de una actitud previa, incluso cuando ella resulta tan lejana en el tiempo?

Este deber de coherencia, además, alcanza tanto a la justicia ordinaria como a la arbitral. Así, por ejemplo, en Errázuriz con Banco BHIF la Corte de Santiago sostuvo, a propósito de una demanda de cumplimiento de obligaciones emanadas de la cuenta de ajuste de una compraventa, que el árbitro tiene competencia para conocer de ella gracias a la cláusula compromisoria y que negarle dicha atribución va contra acto propio, de modo que quien acudió al arbitraje no puede luego intentar desconocer la competencia del árbitro ante un laudo desfavorable ${ }^{4}$.

${ }^{1}$ Art. 2 letra d), Ley 20.886 de 2015, modifica el Código de Procedimiento Civil, para establecer la tramitación digital de los procedimientos judiciales: "Buena fe procesal. Las partes, sus apoderados y todos quienes intervengan en el proceso deberán actuar de buena fe. (2) El tribunal, de oficio o a petición de parte, deberá prevenir, corregir y sancionar, según corresponda, toda acción u omisión que importe un fraude o abuso procesal, colusión, contravención de actos propios o cualquiera otra conducta ilícita, dilatoria o de cualquier otro modo contraria a la buena fe". Sobre el contenido y los alcances de la ley de tramitación electrónica en relación con el Código de Procedimiento Civil, véase Larroucau, J., "Adiós a las fojas. Reglas procesales, autos acordados y tramitación electrónica en Chile”, en Revista de Derecho Privado (Universidad Externado de Colombia), No 33, 2017, pp. 212-219.

${ }^{2}$ Por ejemplo, en Isella con Canal 13 se hizo hincapié en "la aceptación por parte del demandante de la existencia de una relación de naturaleza civil con sus respectivas consecuencias, durante más de quince años, sin haber formulado reclamo alguno [en cuanto a la existencia de un contrato de trabajo con la empresa demandada]"), Corte Suprema, 20 diciembre 2006, Rol No 2.450-2005, CL/JUR/3885/2006, cons. $8^{\circ}$ (Cuarta Sala).

${ }^{3}$ Corte Suprema, 27 octubre 2006, Rol No 3.671-06 citada en CarretTa, F., "Deberes procesales de las partes en el proceso civil chileno”, en Revista de Derecho (Universidad Austral), Vol. 21, N 1, 2008 , p. 122.

${ }^{4}$ Corte de Apelaciones de Santiago, 12 marzo 1999, Rol No 2.998-2002 (redacción del Ministro Manuel Hazbún) analizada en VÁsquez, M. F., "Revisión de la competencia del árbitro en relación al tiempo y la materia”, en Ius et Praxis, Vol. 16, No 2, 2010, pp. 446-447. 
Asimismo, este deber plantea el desafío de vincular conductas que tienen lugar en diversos juicios. Un ejemplo que ilustra este nexo lo entrega la protección de derechos fundamentales del art. 20 de la Constitución de 1980, ya que si una Corte ordena realizar una conducta y el recurrido cumple con dicha orden, luego no puede cuestionar ante un Juzgado Civil lo que ordenó la Corte. En este sentido, la frase constitucional "sin perjuicio de los demás derechos que pueda hacer valer ante la autoridad o los tribunales correspondientes" implica "una 'no aceptación' de lo ordenado por el tribunal de protección [...] lo que no se aviene con el cumplimiento libre de lo allí resuelto" 5 . En otras palabras, no ir contra acto propio en un escenario como este supone necesariamente que, si se cumple con la orden judicial, se crea una legítima expectativa de que el caso se solucionó, de modo que no cabe ir a juicio otra vez.

¿Bastaría con un solo acto, entonces, como el cumplimiento de una orden judicial, para provocar esta expectativa normativa, aunque la ley aluda a esta forma de infringir la buena fe procesal en plural, como "contravención de actos propios"?

Este trabajo analiza desde un punto de vista procesal esta clase de interrogantes, con el propósito de establecer el contenido y los límites de la prohibición de ir contra acto propio en la litigación civil chilena. Para ello se argumenta en el siguiente orden. Primero se introduce la tensión entre la coherencia procesal que es exigible a los litigantes y el derecho de defensa que garantiza el texto constitucional, en el marco de una ley procesal que equilibra intereses privados y públicos. En segundo lugar se identifican las dos tesis - una amplia y otra restringida- que han utilizado las juezas y jueces civiles para aplicar el deber procesal de coherencia que funda la prohibición de ir contra acto propio.

En tercer término se distingue entre el rol secundario que cumple este deber en la motivación de los fallos y su aplicación residual. Es en este último plano que el deber de coherencia instala un control judicial permanente de la argumentación jurídica del litigante ante situaciones de abuso, engaño y actuaciones manifiestamente dilatorias. En este punto se hace una mención especial a los procedimientos laborales, en donde el problema de la contravención de acto propio ha sido profusamente discutido, cuya conclusión es aplicable por analogía a otras formas de litigación semejantes. Por último, se precisa el efecto que acarrea la infracción de este deber procesal, cual es la inadmisibilidad del acto incoherente, así como su compatibilidad con otras medidas específicas que sirven para inhibir las infracciones a la buena fe procesal, como pagar las costas e indemnizar los perjuicios.

${ }^{5}$ Dougnac, F., "Reflexiones sobre la acción de protección y su sentencia", en Revista Chilena de Derecho, Vol. 28, $\mathrm{N}^{\circ}$ 3, 2001, p. 626 (concluye de esta interpretación que "en este caso, el efecto de la sentencia de protección devendría, por la fuerza de los hechos, en cosa juzgada material”).

${ }^{6}$ Carretta, F. "¿Los actos propios en el proceso civil? A propósito del principio de la buena fe procesal y su incorporación en la Ley 20.886 sobre Tramitación Electrónica en el procedimiento civil chileno”, en Revista de Derecho Privado (Universidad Externado de Colombia), No 35, 2018, p. 334 (se inclina por "una serie de actos" como condición necesaria para aplicar la prohibición de ir contra acto propio). 


\section{El DeBER PROCESAL DE COHERENCIA}

Antes de que tuviera vigencia legal, la jurisprudencia civil chilena había considerado a la prohibición de ir contra acto propio como un principio general del derecho ${ }^{7}$. Así como lo señaló la Corte Suprema, por ejemplo, en Vergara con Sociedad de Inversiones Cenit Ltda., esta prohibición persigue, "al amparo del principio general de la buena fe, conseguir un mínimo de coherencia entre la conducta del sujeto y sus pretensiones judiciales y un comportamiento consecuente" 8 .

Este "mínimo de coherencia" cuando se litiga es necesario porque la litigación civil se asemeja a un juego, aunque no en un sentido de decisiones inmanentes (i. e., al "jugar" de cierta manera un resultado es inevitable, como el jaque mate en el ajedrez), sino como decisiones dirimentes (i.e., una actividad dinámica que tolera cierto margen de discrecionalidad en las decisiones de los sujetos procesales) ${ }^{9}$.

De allí que la litigación -al igual que un juego- pueda ser analizada (1) desde el punto de vista de sus resultados, examinando la creación de sus reglas (por el Parlamento) o su aplicación (por los tribunales), o bien, (2) desde la óptica de la actividad misma ${ }^{10}$. En este último caso la categoría clave es la del debido proceso.

Desde esta última perspectiva, la prohibición de ir contra acto propio da cuenta de una tensión entre la coherencia procesal que la litigación requiere y el derecho de defensa que se garantiza constitucionalmente ${ }^{11}$. En una frase que a menudo se repite

${ }^{7}$ Por todas: Corte de Apelaciones de Santiago, 30 enero 2014, Rol N ${ }^{\circ} 1.731-2013$, cons. $5^{\circ}$ y $6^{\circ}$ (Duodécima Sala: redacción del Ministro Juan Cristóbal Mera) (se rechaza la pretensión del actor de que se le indemnice un corte en la cara que habría sufrido porque la empresa permitió que en uno de los puentes que atraviesan la autopista colgase un hilo con vidrio molido, ya que el mismo día del accidente el propio demandante declaró a un canal de televisión que vio un volantín cerca de su cara aunque no el hilo, de modo que el accidente se produjo por un hecho de tercero) analizada en MoralEs, M. E., "La prohibición de ir contra acto propio como manifestación de la exigencia al consumidor de actuar conforme a los parámetros de la buena fe (Corte de Apelaciones de Santiago)", en Revista de Derecho (Universidad Austral), Vol. 27, $\mathrm{N}^{\mathrm{o}} 1,2014$, pp. 247-251.

${ }^{8}$ Corte Suprema, 26 enero 2011, Rol N 3.450-2009 citada en PADILla, R., "Por una correcta aplicación de la doctrina de los actos propios", en Revista Chilena de Derecho Privado, No 20, 2013, pp. 151-152.

9 Carrasco, N., "El proceso civil como juego no repetitivo y como vía para interiorizar cargar informativas: Una mirada desde el análisis económico del derecho”, en Revista Chilena de Derecho, Vol. 44, $\mathrm{N}^{\circ}$ 1, 2017, pp. 190, 198 (considera al proceso civil "como un juego único y no reiterativo que tiende a la interiorización de las expectativas de éxito y fracaso de las partes [...] un juego único procesal como vía para interiorizar cargas argumentativas").

${ }^{10}$ Bone, R., "Procedure, Participation, Rights", en Boston University Law Review, 90, 2010, pp. 1025-1028.

${ }^{11}$ En un lenguaje estrictamente constitucional esta tensión puede describirse como una oposición entre el derecho (fundamental) a una tutela judicial efectiva y el derecho (fundamental) de defensa: HuNTER, I., "No hay buena fe sin interés: La buena fe procesal y los deberes de veracidad, completitud y colaboración", en Revista de Derecho (Universidad Austral), Vol. 21, N 2, 2008, pp. 158-164 (sostiene una posición escéptica en cuanto al fundamento constitucional del principio de buena fe procesal); Picó i Junoy, J., "El debido proceso "leal". Reflexiones en torno al fundamento constitucional del principio de la buena fe procesal", en Revista Peruana de Derecho Procesal, Vol. 9, 2006, pp. 331 ss (argumenta desde una perspectiva constitucional en favor de la buena fe procesal). 
en las decisiones de los tribunales chilenos: "Los actos propios encuadran el derecho de los litigantes" 12 .

Este "encuadre" genera una pugna entre ser coherente en el juicio y defenderse lo mejor posible. Para establecer un equilibrio a este respecto es preciso notar que las regulaciones procesales se han desplazado desde una concepción que privilegió la defensa (como en el Code de Procédure Civile francés de 1806) hacia una que promueve la colaboración (como en las Civil Procedure Rules inglesas de 1998 y en la Zivilprozessordnung alemana de 2002). El desafío, entonces, es conseguir este equilibrio entre defensa y coherencia asumiendo que "vivimos en un mundo de híbridos", para decirlo con William Twining ${ }^{13}$.

La tensión descrita explica que la prohibición de ir contra acto propio se haya interpretado judicialmente de más de una forma: a veces, dando más importancia a la colaboración con los jueces; en otras, en cambio, siendo deferente con la defensa de las partes y sancionando solo las actuaciones abusivas.

\section{LA PROHIBICIÓN DE IR CONTRA ACTO PROPIO EN LA JURISPRUDENCIA CIVIL}

La cláusula de buena fe procesal tiene como propósito impedir que el interés de las partes cancele los compromisos que sirve la administración de justicia. La fórmula que emplea la ley chilena no se limita a prohibir el dolo o la mala fe en la litigación, sino que permite imponer ciertas cargas y deberes orientados a la colaboración con el juez ${ }^{14}$. Entre estos deberes se cuenta el de la coherencia argumentativa, el que morigera el derecho de defensa de las partes. Así, por ejemplo, si un banco manifiesta su voluntad de cobrar todo el crédito a su favor mediante una demanda ejecutiva y gracias a que cuenta con una cláusula de aceleración, luego no puede desdecirse alegando la interrupción del plazo de prescripción ${ }^{15}$.

La prohibición de ir contra acto propio ha tenido aplicación en toda la justicia civil chilena, sea patrimonial, de familia o del trabajo. Así, en los conflictos patrimoniales,

12 Por todas: Jahr y Cía. Ltda. con Param, Corte de Apelaciones de Concepción, 18 agosto 2014, Rol No 581-2014, CL/JUR/5573/2014, cons. $5^{\circ}$ (Sexta Sala: redacción de la Ministra Matilde Esquerré).

13 Twining, W., Retbinking Evidence. Exploratory Essays, Cambridge University Press, $2^{a}$ Edición, 2006, p. 196.

${ }^{14}$ Larroucau, J., "Tres lecturas de la buena fe procesal”, en Revista Chilena de Derecho Privado, $\mathrm{N}^{\circ} 21$, 2013 , p. 265.

15 TAVOlaRi, R., "De la aceleración, la interrupción de la prescripción y la doctrina de los actos propios en el proceso", en Gaceta Jurídica N $\mathrm{N}^{\circ} 188,1996$, pp. 100-103. En igual sentido: Compañía Contractual Minera Los Andes con Ponce, Corte de Apelaciones de Copiapó, 10 octubre 2014, Rol No 186-2014, CL/ JUR/7371/2014, cons. $5^{\circ}$ (redacción del Ministro Francisco Sandoval) ("si habiendo ejecutado una actuación en nombre, interés y beneficio de la sociedad demandada -cual es, notificarse personal y voluntariamente de la demanda de oposición a la mensura incoada-, pretende luego que se desconozca validez a dicha gestión, conjuntamente con el resto de lo obrado en los autos, invocando una circunstancia que conocía desde el inicio [el litigante va contra acto propio]"). 
por ejemplo, ella se ha invocado en casos de nulidad contractual, precario, reivindicación, prescripción, pago de las rentas del arrendamiento, interpretación del contrato, indemnización de daños, ejecución, arbitraje, entre muchos otros ${ }^{16}$. Su empleo, en todos estos casos, no ha sido uniforme: (1) en algunas circunstancias los jueces la han interpretado de una forma amplia, cuestionando no solo el modo en que la parte presenta sus argumentos, incluso cuando se vale de potestades que le atribuye la ley, sino que la posibilidad misma de ir a juicio; (2) en otras ocasiones, en cambio, se ha resuelto que este deber solo puede ser un límite a las conductas abusivas, fraudulentas o manifiestamente dilatorias.

\section{Aplicación amplia}

La concepción extensiva de este deber de coherencia puede limitar severamente el acceso a la justicia de las personas. Para evidenciarlo es útil acudir a un par de ejemplos tomados de la litigación civil acerca de contratos y propiedad, en relación con el modo en que se interpone una demanda. En el conocido caso Villanueva con Sanhueza, la actora demandó la nulidad (absoluta) del contrato alegando simulación, a pesar de que en un juicio anterior había solicitado su nulidad (relativa) por lesión enorme. La Corte Suprema falló en contra de los intereses de la actora al considerar que su conducta no era "leal y honesta" 17 , no obstante que la propia ley permite alegar "acciones incompatibles" en un juicio ${ }^{18}$.

A primera vista, entonces, pareciera que la solución a este reparo habría sido acumular las "acciones incompatibles" de la actora en un mismo juicio, presentando una en subsidio de la(s) otras(s). Pero lo cierto es que una interpretación amplia del deber de coherencia también censura este tipo de estrategias. Así, por ejemplo, en Vera con Municipalidad de Puerto Montt, el actor interpuso ("en lo principal”) una acción de "mera certeza" de su dominio y ("en subsidio") una acción para que se "declare que el inmueble que posee constituye un resto no expropiado" de un terreno adquirido, en último término, por prescripción. En primera instancia, el Segundo Juzgado Civil de Puerto Montt no dio lugar a la demanda, rechazando tanto la acción principal como la subsidiaria, decisión que sería confirmada por la Corte de Puerto Montt con el siguiente argumento:

"Ejercidas una y otra pretensión en un mismo libelo revelan debilidad en la confianza de la teoría del caso y del derecho en que se sustenta y ejerce, y una manipulación perversa de las facultades que proporciona el ordenamiento procesal, que se contrapone

${ }^{16}$ Contardo, J. I., "La doctrina de los actos propios en la jurisprudencia civil chilena", en Venire contra factum proprium. Escritos sobre la fundamentación, alcance y límites de la doctrina de los actos propios, Hernán Corral editor, Cuadernos de Extensión, Nº 18, 2010, pp. 81 ss.

${ }^{17}$ Corte Suprema, 09 mayo 2001, MJCH_MJJ7138, cons. $3^{\circ}$ (redacción del Abogado Integrante René Abeliuk) analizada en Romero, A., "El principio de buena fe procesal y su desarrollo en la jurisprudencia, a la luz de la doctrina de los actos propios", en Revista Chilena de Derecho, Vol. 30, No 1, 2003, pp. 167-172.

${ }^{18}$ Art. 17 Código de Procedimiento Civil: "En un mismo juicio podrán entablarse dos o más acciones con tal que no sean incompatibles. (2) Sin embargo, podrán proponerse en una misma demanda dos o más acciones incompatibles para que sean resueltas una como subsidiaria de otra”. 
al principio de buena fe que debe imperar entre los litigantes, pues se extralimita con el abuso del derecho, igualmente vedado a los litigantes" 19 .

\section{Un razonamiento muy similar empleó la Corte Suprema en Vásquez y Arriagada} con Vicariato Apostólico Aysén, en donde el actor interpuso ("en lo principal”) una acción reivindicatoria y ("en subsidio") una acción de nulidad del contrato, lo que dio lugar a una demanda cuya argumentación jurídica fue considerada confusa ${ }^{20}$.

Como se puede observar, esta forma amplia de interpretar el deber de coherencia termina cancelando una posibilidad que la propia ley procesal le reconoce al actor en cuanto al modo de presentar los fundamentos de su demanda; regla que, por lo demás, en el Proyecto de Código Procesal Civil de 2012 (Boletín No 8197-07) se mantiene ${ }^{21}$. Esta restricción argumentativa no es menor si se considera que se trata de una estrategia sumamente frecuente, por ejemplo, en los juicios de responsabilidad civil $^{22}$ y en casos de restitución de bienes ${ }^{23}$.

Si el actor introduce varias pretensiones, de modo tal que con ello incluso puede cambiar el objeto procesal (por ejemplo, cuando se demanda el cumplimiento de un contrato y, en subsidio, su resolución), el juez debería ser deferente con el orden de prelación en que el demandante ha presentado sus peticiones y fundamentos ${ }^{24}$, sin declarar inadmisible la demanda por estimarla incoherente, salvo en casos excepcionales como el de Vásquez y Arriagada, recién citado. Esta deferencia con la forma en que el actor

19 Corte de Apelaciones de Puerto Montt, 04 de marzo de 2014, Rol No 45-2013, MJJ37266 (redacción del Ministro Leopoldo Vera) analizada en Larroucau, J., "Demandas abusivas”, en La buena fe en la jurisprudencia: comentarios y análisis de sentencias, Lilian San Martín (editora), Silvia Retamales y Valentina Guevara (coordinadoras), Thomson Reuters, Santiago de Chile, 2015, pp. 51-61.

${ }^{20}$ Corte Suprema, 17 junio 2015, Rol No 22.264-2014, CL/JUR/3405/2015, cons. $4^{\circ}$ (Primera Sala: redacción del Ministro Guillermo Silva) ("no es posible soslayar que los supuestos de hecho y derecho que esgrimió la actora para fundamentar su pretensión reivindicatoria no resultan claros, pues al explicar la procedencia de la acción afirmó en su demanda, indistintamente, que los títulos que sirven de antecedente a la posesión inscrita que beneficia a la demandada adolecen de vicios de validez y también señala, solamente al pasar, sin mayor basamento y sin hacer petición alguna sobre ello, que tales actos le son inoponibles a su parte, por dar cuenta de una venta de cosa ajena, confusión que la petición subsidiaria acrecienta aún más, pues se endereza precisamente con el objeto de obtener la declaración de nulidad de las compraventas").

${ }^{21}$ Art. 51 Proyecto de Código Procesal Civil de 2012: "De la pluralidad inicial objetiva de acciones. El actor podrá ejercer conjuntamente en una misma demanda varias acciones o pretensiones en contra un mismo demandado, aunque provengan de diferentes títulos, con tal que no sean incompatibles entre sí. (2) Sin embargo, podrán proponerse en una misma demanda dos o más acciones incompatibles para que sean resueltas una como subsidiaria de la otra. (3) También se tramitarán conjuntamente en una misma demanda distintas acciones cuando así lo dispongan las leyes".

${ }^{22}$ Larroucau, J., "La opción de responsabilidad civil como un acertijo procesal", en Estudios de Derecho Civil VII, Fabián Elorriaga coordinador, Thomson Reuters, Santiago de Chile, 2012, pp. 461 ss.

${ }^{23}$ Corte de Apelaciones de Santiago, 19 julio 1993, LegalPublishing $N^{\circ} 20196$, cons. $6^{\circ}$ y $7^{\circ}$ (redacción del Ministro Juan Araya) (en este caso el arrendatario dejó de pagar la renta y el arrendador demandó, en lo principal, el término del contrato por incumplimiento de una obligación y, en subsidio, la restitución por la vía del precario, lo que "pugna con la doctrina de los actos propios").

${ }^{24}$ Larroucau, J. y Rostión, I., "Del juicio de precario", en Fundamento de derechos reales en el derecho chileno, Rodrigo Barcia Lehmann compilador, Thomson Reuters, Santiago de Chile, 2013, pp. 76-78. 
decide presentar su caso no significa, por cierto, que si el tribunal rechaza la acción principal y acoge una subsidiaria, el demandante pueda acudir a una Corte a impugnar tal decisión por este solo motivo ${ }^{25}$.

En definitiva, esta versión amplia del deber de coherencia -una "teoría expansiva del acto propio"- ${ }^{26}$ puede incidir no solo en el derecho de defensa durante el juicio, sino que, antes que esto, puede vulnerar el acceso a la justicia o tutela jurisdiccional de la persona.

Es interesante añadir que esto suele ocurrir cuando el antecedente no es una acción, sino una omisión. Así, por ejemplo, en Dubalde con Lang y Ríos, la Corte Suprema consideró que al no haberse interpuesto un incidente de nulidad de la subasta en el propio juicio ejecutivo no se podía, más adelante, pretender la nulidad de la misma en un juicio declarativo ${ }^{27}$. En Intequip Mining Sales and Services Ltd. con Altamirano, en tanto, la Corte Suprema sostuvo que al no haberse pedido la incompetencia del tribunal al comienzo del juicio, no se podía luego recurrir en contra de la sentencia señalando que el asunto estaba reservado a la justicia arbitral ${ }^{28}$. Y, en Sociedad Aránguiz Romero y Oso con Mainar Chile Limitada, por su parte, se impidió que la demandada se opusiese a la ejecución de la sentencia porque supuestamente no había sido emplazada en el juicio, si estaba claro que había podido defenderse durante el litigio ${ }^{29}$.

\section{Aplicación restringida}

La concepción restringida de la prohibición de ir contra acto propio, en cambio, se limita a los casos de abuso, engaño y conductas manifiestamente dilatorias. Este rol se

${ }^{25}$ Por todas: Pomés con Isapre Cruz Blanca S.A., Corte Suprema, 09 marzo 2016, Rol No 9.555-2015, CL/JUR/1631/2016, cons. $10^{\circ}$ (Primera Sala: redacción del Abogado Integrante Álvaro Quintanilla) ("las alegaciones planteadas por la recurrente bajo el acápite que se analiza resultan improcedentes ya que contrarían lo que ha sido su propio actuar procesal, desde que la misma planteó aunque sea en forma subsidiaria una acción indemnizatoria de perjuicios sustentada como se ha dicho en la responsabilidad contractual que le imputa a la demandada, aceptando con ello la procedencia de la aplicación al caso de dicha regulación normativa por el tribunal, lo que le resta toda legitimidad para contrariar la decisión de los jueces de alzada, pues desconoce su propio proceder, alterando, por lo demás, el tenor de la litis”).

${ }^{26}$ GANDUlfo, E., "La aplicación del principio "venire contra factum proprium non valet". Un caso de vulgarismo jurídico”, en Revista Chilena de Derecho, Vol. 32, No 2, 2005 , p. 364.

${ }^{27}$ Corte Suprema, 19 diciembre 2011, Rol N 2.909-2011, CL/JUR/10029/2011, cons. $9^{\circ}$ (Primera Sala: redacción del Ministro Juan Araya). En el mismo sentido: Figueroa con Reñasco y otra, Corte Suprema, 11 junio 2012, Rol No 3.806-2012, CL/JUR/3958/2012, cons. $4^{\circ}$ (Primera Sala) ("los jueces del mérito desconocen la legitimidad del actor para impetrar la nulidad, desde que su conducta pugna con la buena fe, al contravenir aquella desplegada en el juicio seguido en su contra, con la cual les confirió validez a los efectos de la subasta, tanto por no solicitar la nulidad del acto como por requerir el giro de cheques a propósito del remate").

${ }^{28}$ Corte Suprema, 14 noviembre 2016, Rol No 45.787-2016, CL/JUR/7580/2016, cons. $10^{\circ}$ (Primera Sala).

29 Corte de Apelaciones de Santiago, 10 febrero 2016, Rol N ${ }^{\circ}$ 10.952-2015, CL/JUR/1619/2016, cons. $6^{\circ}$ (Séptima Sala: redacción de la Ministra María Soledad Melo) ("no puede aceptarse que el apelante, en el momento en que es requerido el cumplimiento incidental del fallo, sostenga el desconocimiento de la acción como persona natural, desde que las actuaciones en el proceso por él efectuadas, importaron una cabal inteligencia de la demanda deducida”). 
puede graficar con el caso Inmobiliaria Alameda de Antofagasta con Vergara. Aquí la actora reivindicó en contra de alguien que detentaba injustamente un inmueble y que de forma previa había ganado otros dos juicios sobre el mismo bien: uno por incumplimiento de contrato, al negar la existencia del arrendamiento, y uno de precario, en donde, por el contrario, el demandado hizo valer en su favor el arrendamiento como título para justificar la tenencia. En este tercer juicio -el reivindicatorio-, el mismo arrendamiento (celebrado con la anterior dueña del inmueble) también le sirvió al demandado para vencer en la segunda instancia. Pero finalmente sería la Corte Suprema quien le pondría freno a estas maniobras porque, aunque dichas actuaciones ocurrieron en juicios distintos, merecían una censura: la "actitud es contraria a derecho, ya que contraviene el principio jurídico de la doctrina de los actos propios" 30 .

Con todo, este fallo contó con un voto en contra, del ministro Milton Juica, en cuya opinión todas estas "alegaciones formuladas en causas distintas constituyen el legítimo ejercicio del derecho de defensa que le asegura la Constitución Política”.

Desde un punto de vista restringido, entonces, este deber de coherencia permite sancionar hipótesis de abuso o fraude, por ejemplo, cuando un deudor emplea una empresa en la que participa para constituir una hipoteca sobre el inmueble que debe ser subastado en un juicio ejecutivo e impedir de este modo que se pague la deuda, así como ocurrió en Salvo y otros con Inmobiliaria Bergneustadt Limitada ${ }^{31}$. En este mismo sentido, en Sociedad Inmobiliaria Puerto Varas Limitada con Comercializadora de Alimentos Mediterráneo Limitada, se dejó sin efecto el alzamiento de una medida precautoria -que le permitió al demandado vender el inmueble al día siguiente, a un exsocio de la empresa demandada- porque el Receptor Judicial dejó constancia de tal diligencia con casi un mes de retraso, impidiendo que la demandante hiciese valer sus derechos. El tribunal consideró que se había infringido el principio de la buena fe procesal en su variante específica que prohíbe ir contra acto propio, porque en una audiencia posterior a la venta del inmueble la demandada se mostró dispuesta a conciliar esgrimiendo como garantía del cumplimiento del acuerdo la medida precautoria que ella misma había logrado alzar, por lo que sabía que no estaba vigente ${ }^{32}$.

${ }^{30}$ Corte Suprema, 30 mayo 2007, Rol No 4.680-2005, MJJ10201, cons. $10^{\circ}$ analizada en PÉrEz, M. F., "La protección del dueño ante quien retiene indebidamente un bien. Análisis jurisprudencial del artículo 915 del Código de Bello”, en Revista de Derecho (Universidad Católica del Norte), 21, Nº 1, 2014, pp. 416-417.

${ }^{31}$ Corte Suprema, 14 marzo 2017, Rol No 35.542-2016, CL/JUR/901/2017, cons. $24^{\circ}$ (Primera Sala: redacción del Ministro Guillermo Silva) ("la improcedencia del actuar de la ejecutada, por cuanto pretende desconocer la posición que sus antecesores en dominio y luego sus únicos socios tuvieron al celebrar el acto por el cual constituyeron la hipoteca de que se trata, en los términos que lo hicieron, desconociendo o contrariando lo que fue su posición jurídica en el mismo, cuestionando la legitimidad de las estipulaciones que éstos convinieron para así eludir la satisfacción de las obligaciones cuyo cumplimiento pretendió ser asegurado por la garantía hipotecaria, de cuya existencia estaban en pleno conocimiento conforme a la propia declaración que los mismos formularon y en condiciones de conocer el contenido íntegro de la misma, según la inscripción que también reconocen”).

32 Juzgado de Letras de Puerto Varas, 07 diciembre 2018, Rol N 1.362-2018, cons. $5^{\circ}$ (Redacción de la Jueza Lorena Lemunao). 
En conclusión, bajo cualquiera de los enfoques señalados, el deber de coherencia que funda la prohibición de ir contra acto propio suscita varios interrogantes que es preciso responder: ¿Cómo se pueden alegar en un juicio argumentos que son incompatibles entre sí, pero útiles a los intereses de la parte?, ¿se puede cambiar el argumento jurídico cuando se recurre ante una Corte ${ }^{33}$, ¿qué limitaciones se derivan de los juicios ya litigados?, ¿estos juicios deben haberse litigado con la misma parte o también cuentan los juicios con terceros? Como se ve, la prohibición de ir contra acto propio no contiene una respuesta clara para estos asuntos. No obstante, lo que ella sí ha puesto de manifiesto es la necesidad de aproximarse a la litigación civil como un sistema y no como un compendio de casos aislados.

Para dar realce a la importancia de este giro es oportuno aludir a dos situaciones más, las que muestran el tradicional vínculo que ha habido entre la prohibición de ir contra acto propio como expresión de la buena fe procesal y la cosa juzgada como forma de clausurar los litigios.

En De la Fuente con Williamson Balfour Motors Distribuidora S.A., a propósito de un accidente de tránsito, se resolvió que en el juicio de responsabilidad civil en contra de la empresa no se podía controvertir que el seguro no operó porque el conductor no dejó constancia a tiempo del accidente, ya que este hecho fue probado tanto en el juicio penal (que concluyó con una suspensión condicional del procedimiento) como en el juicio civil en contra del conductor ${ }^{34}$. El deber de coherencia, entonces, se conecta con la prejudicialidad, modulando de este modo las posibilidades de defensa en un juicio que tiene relación con otros 35 .

33 Un buen caso para discutir esta pregunta es Inversiones Disal S.A. con Salinas. En aquel juicio la actora se impuso en favor de la actora, aunque la demandada desconoció que el inmueble estuviese en su poder (Juzgado de Letras de Melipilla, 27 agosto 2007, Rol No 64.292, LegalPublishing $\mathrm{N}^{\circ} 43499$, cons. $8^{\circ}$, redacción de la Jueza Angélica Pérez), decisión que fue revocada en segunda instancia debido a un cambio en la valoración de la prueba -los testigos presenciales de la demandante pasaron a ser considerados testigos de oídas- (Corte de Apelaciones de San Miguel, 30 junio 2008, Rol N 24-08, LegalPublishing N 43499 , cons. $9^{\circ}$, redacción de la Ministra María Soledad Espina). La Corte Suprema, en tanto, dejó sin efecto el fallo de segunda instancia y se pronunció en favor de la actora considerando la conducta del demandado contraria a la buena fe procesal, debido a "la contradicción y falta de coherencia entre el escrito de fojas 53 (patrocinio y poder presentado por el señor Salinas Urrutia, en que fija su domicilio en Los Jazmines $\mathrm{N}^{\circ} 015$, Melipilla) y las cuatro alegaciones en que se funda el recurso de apelación acogido por el tribunal de segunda instancia (todas las cuales plantean que no es él quien ocupa el inmueble requerido por el demandante)" (Corte Suprema, 24 marzo 2010, Rol N 5.698-08, LegalPublishing No 43499, redacción de la Abogada Integrante Maricruz Gómez de la Torre).

${ }^{34}$ Corte Suprema, 9 noviembre 2017, Rol No 4.669-2017, CL/JUR/7177/2017, cons. $10^{\circ}$ (Primera Sala: redacción del Ministro Juan Eduardo Fuentes) (" [la recurrente] no puede pretender cuestionar la responsabilidad de dicho sujeto [el conductor] si antes aceptó esa misma circunstancia y pretendió obtener provecho de ello, asilándose en una interpretación normativa que no enarboló cuando no le convenía cuestionar la responsabilidad [del conductor]”).

${ }^{35}$ En esta misma senda: Vera con Melgarejo y otro, Corte Suprema, 5 abril 2018, Rol No 34.262-2017, CL/JUR/1566/2018, cons. $8^{\circ}$ (Primera Sala: redacción de la Ministra Andrea Muñoz) ("si durante el juicio el demandado Miranda Melgarejo no desconoce que el pago que el conductor del camión de su propiedad realizó en el juicio penal seguido en su contra se refiere a los mismos hechos de este proceso, mal puede en 
En Ortega y Aravena con Empresa Nacional de Electricidad S. A., en tanto, se consideró que había una incoherencia entre un primer juicio en que se demandó la resolución de un contrato con indemnización de perjuicios y, un segundo juicio, en que se solicitó la nulidad del mismo contrato ${ }^{36}$. Este tipo de situaciones demuestra que la prohibición de ir contra acto propio puede cubrir casos que la cosa juzgada no logra impedir, debido a que el objeto pedido es diverso.

De este modo, la prohibición de ir contra acto propio anticipa en algún sentido el cambio que se propone en el Proyecto de Código Procesal Civil de 2012, en cuanto a eliminar la triple identidad (art. 177 Código de Procedimiento Civil/CPC) de la excepción de cosa juzgada y reemplazarla por la categoría del "objeto virtual" (o de "lo deducido y lo deducible"), de manera que el efecto negativo o excluyente de la cosa juzgada dependa solo de "que se pretenda un nuevo juzgamiento de lo ya resuelto" (art. 216) ${ }^{37}$. Este deber de coherencia, cuando se lo interpreta de forma amplia, termina por imponerle al juez la ardua tarea de analizar no solo lo que el litigante sostuvo en otro(s) juicio(s) que se relacionan con el actual, sino que también aquello que pudo haber alegado en su favor, pero por un motivo u otro no hizo.

\section{IV. "UN ESCUDO, NO UNA ESPADA"}

La aplicación judicial de este deber de coherencia fue resumida en la cultura jurídica angloamericana con esta frase: "La prohibición de ir contra acto propio brinda un escudo, no una espada" (estoppel provides a shield, not a sword) $)^{38}$. En lo que respecta a la justicia civil chilena, en tanto, para evitar una aplicación desmesurada de este deber y, con ello, una vulneración de los derechos constitucionales ligados al debido proceso

su recurso de casación controvertir la responsabilidad de ese sujeto ya que, considerarlo de otro modo, sería olvidar que la teoría de los actos propios protege, en último término, la buena fe objetiva"); De Caso con Bofill, Corte Suprema, 13 septiembre 2007, Rol No 169-05, cons. $12^{\circ}$ (redacción del Abogado Integrante Arnaldo Gorziglia) ("a nadie le es lícito hacer valer un derecho civil o procesal en contradicción con su anterior conducta jurídica [lo cual] impide jurídicamente el que una persona afirme o niegue la existencia de un hecho determinado, en virtud de haber ejecutado antes un acto, hecho una afirmación o formulado una negativa en el sentido precisamente opuesto").

${ }^{36}$ Corte de Apelaciones de Concepción, 04 septiembre 2013, Rol No 374-2013, CL/JUR/1979/2013, cons. $5^{\circ}$ y $8^{\circ}$ (redacción del Abogado Integrante Carlos Céspedes) ("la presentación posterior de una demanda de nulidad absoluta del mismo contrato importa el ejercicio de una pretensión antagónica con la conducta anteriormente exteriorizada, dado que ahora contradictoriamente solicitan la ineficacia de un acto jurídico que consideraron plenamente válido en una oportunidad anterior”).

${ }^{37}$ El Mensaje del Proyecto de Código Procesal Civil de 2012 alude a este cambio al decir que, "en materia de cosa juzgada, recogiendo las tendencias modernas en esta materia, se regula su efecto positivo o prejudicial, e innovando en lo que ha sido tradicional, se elimina la triple identidad como factor determinante para la configuración de la fase negativa de este instituto. Se mantiene, como es indispensable, la identidad subjetiva, pero se entregan los demás elementos al análisis identitario [sic] que efectúe razonadamente el tribunal, con el fin de impedir la dictación de sentencias contradictorias y el iniciar procesos que versen sobre asuntos ya decididos por sentencias ejecutoriadas".

${ }^{38} \mathrm{La}$ referencia es a la jurisprudencia inglesa: Combe v. Combe (1951) 2 KB 215. 
y una vulgarización de otras categorías procesales, es preciso formalizar su ámbito de aplicación. Esto implica identificar las condiciones de operatividad que la distinguen de otras formas -como la colusión entre litigantes, por ejemplo- también incluidas en la ley como casos típicos de infracción a la buena fe procesal.

Un camino a seguir, claro está, es el de la tipificación legal de ciertas situaciones en que se contradice un acto propio. En este sentido, el Código de 1903 contempla supuestos específicos de protección a la confianza legítima provocada por la conducta de uno de los litigantes: por ejemplo, pedir la incompetencia del tribunal mediante una declinatoria o una inhibitoria, en donde la elección de una vía hace precluir la posibilidad de optar por la otra y no pueden intentarse ambas de forma simultánea (art. 101 inciso 2 CPC), o bien, la imposibilidad de modificar las causales de casación -en el fondo o en la forma- una vez interpuesto el recurso (art. 774 CPC).

La ley chilena ha cultivado esta senda especialmente en la justicia de familia, guiando el trabajo de los jueces mediante escenarios típicos. Así, por ejemplo, la multa por romper un acuerdo de esponsales (art. 99 inciso 2 Código Civil/CC), la paternidad del hijo concebido con anterioridad al matrimonio y reconocido por actos positivos (art. 184 inciso 3 CC), el reconocimiento del padre que el hijo mayor de edad ha aceptado (art. 192 CC), la incorporación al inventario de bienes que el guardador sabe que no pertenecen al pupilo (art. $387 \mathrm{CC}$ ), la renuncia a los gananciales cuando se alega un engaño (art. 1782 CC), el valor atribuido a las solemnidades mediante las cuales se demuestra el cese de la convivencia (art. 22, Ley 19.947 de 2004, ley de matrimonio civil), el nemo tenetur cuando se demanda la separación judicial (art. 26 inciso $3^{\circ}$ Ley 19.947), o bien, el incumplimiento reiterado de las obligaciones alimenticias cuando se demanda unilateralmente el divorcio (art. 55 inciso $3^{\circ}$ Ley 19.947) ${ }^{39}$.

A pesar de todo, debido a que la ley procesal no puede saturar este deber mediante reglas específicas, es la jurisprudencia y la dogmática quienes tienen que identificar en qué otros casos la confianza que generan las conductas de los litigantes amerita acudir a la prohibición de ir contra acto propio para acotar el derecho de defensa.

Este desafío requiere del auxilio de otras categorías procesales, mejor delineadas por la práctica judicial, lo que se traduce en que la prohibición de ir contra acto propio suela ir acompañada de otros argumentos en la motivación de las sentencias. Esta circunstancia hace necesario distinguir entre una aplicación secundaria (obiter dicta) del deber de coherencia y una aplicación residual, siendo esta última un control judicial permanente de la argumentación jurídica de los litigantes ante situaciones de abuso, engaño y actuaciones manifiestamente dilatorias.

Un ejemplo típico del rol secundario -como argumento de refuerzo o "a mayor abundamiento"- del deber de coherencia se halla en la tendencia que desautoriza a la Corte Suprema (o, mejor dicho, en que la Corte Suprema se desautoriza a sí misma) para revisar las intenciones de las partes en un contrato. Para citar solo uno de estos casos:

${ }^{39}$ Corral, H., "La doctrina de los actos propios en el derecho de familia chileno", en Venire contra factum proprium. Escritos sobre la fundamentación, alcance y límites de la doctrina de los actos propios, Hernán Corral editor, Cuadernos de Extensión, N 18, 2010, pp. 103 ss. 
en Aseguradora de Magallanes S.A con Mediterranean Shopping Company S.A., la Corte Suprema estuvo de acuerdo con el abandono de procedimiento -ya que no se había realizado ninguna gestión útil entre mayo de 2002 y diciembre de 2003-, aunque uno de los litigantes se opusiera, debido a que el contrato de compromiso lo habían firmado, precisamente, con el objetivo de mantener en suspenso el juicio ${ }^{40}$.

Este papel secundario en el razonamiento judicial no es extraño porque la coherencia es un estándar de justificación de pretensiones jurídicas de carácter débil (o no imperialista), ya que admite (o, más bien, requiere) colacionar otros criterios en el argumento principal $^{41}$. Este rasgo estructural de la coherencia explica que esta infracción a la buena fe procesal aparezca, con bastante frecuencia, como un obiter dicta en las decisiones judiciales.

Un claro ejemplo de su rol residual, en tanto, es Melo con Melo, un juicio de nulidad de una compraventa por lesión enorme. En primera instancia no se consideró que la demanda fuese incoherente con una renuncia contractual previa a dicha acción de nulidad, porque como la contraparte no habría cumplido con pagar el justo precio, la excepción de contrato no cumplido (art. 1552 CC) hacía viable dicha demanda ${ }^{42}$. Como se puede apreciar, un razonamiento como este le da la razón a Walter Zeiss, en cuanto a que "la prohibición de venire contra factum proprium se toca con el principio del pacta sunt servanda" 43 . Con todo, dicha sentencia sería luego revocada en segunda instancia, al estimarse que el actor había ido contra acto propio ${ }^{44}$, conclusión que la Corte Suprema apoyó $^{45}$.

${ }^{40}$ Romero, A., "El acto propio en materia arbitral: Algunos límites probatorios para su aplicación”, en Venire contra factum proprium. Escritos sobre la fundamentación, alcance y límites de la doctrina de los actos propios, Hernán Corral editor, Cuadernos de Extensión, No 18, 2010, pp. 69 ss. La cláusula de estilo que se emplea en situaciones como esta es bien conocida y comunica de forma clara el argumento principal para rechazar estos recursos. Dicho argumento no es otro que una doble deferencia, tanto con la (libre) negociación de las partes como con la (libre) valoración de la prueba del juez de instancia: "La voluntad e intención plasmada por las partes en un contrato y que los Jueces del fondo llegan a establecer en uso de las facultades que le son propias, constituye un hecho que se presenta inamovible para el Tribunal de casación, no siendo posible impugnarlo mediante la nulidad hecha valer", Corte Suprema, 13 junio 2007, Rol No 5.794-05, cons. 11 ${ }^{\circ}$, LegalPublishing No 36590 (redacción del Abogado Integrante Carlos Künsemüller).

${ }^{41}$ Bertea, S., "The Arguments from Coherence: Analysis and Evaluation", en Oxford Journal of Legal Studies, 25, No 3, 2005, pp. 372-373, 386.

$4226^{\circ}$ Juzgado Civil de Santiago, 21 julio 2005, Rol N 4.162-2002, CL/JUR/7541/2005, cons. $20^{\circ}$ y $21^{\circ}$ (redacción del Juez Humberto Provoste).

43 Zeiss, W., El dolo procesal. Aporte a la precisación teórica de una probibición del dolo en el proceso de cognición civilístico, traducción de Tomas Banzhaf, Ediciones Jurídicas Europa-América, Buenos Aires, 1979 (1967), p. 100.

${ }^{44}$ Corte de Apelaciones de Santiago, 07 abril 2009, Rol N².124-2006, CL/JUR/10058/2009, cons. $5^{\circ}$ (Novena Sala: redacción de la Ministra María Eugenia Campos) ("establecido el hecho que el actor en el año 1995 compró a su hijo mediante escritura pública de 10 de mayo de 1995 la propiedad de Pasaje Aviador Acevedo 2244 de Conchalí, sin reparos, no puede ahora en este pleito contradecir su posesión jurídica anterior, alegando rescisión por lesión enorme del contrato de compraventa de 24 de agosto del 2001, en el cual la parte demandante vende a la parte demandada el mismo inmueble, dándose consecuentemente, todas las exigencias de procedencia del principio que se ha hecho referencia").

${ }^{45}$ Corte Suprema, 13 diciembre 2010, Rol No 3.602-2009, CL/JUR/17169/2010, cons. $14^{\circ}$ (Primera Sala: redacción del Ministro Adalis Oyarzún). 
En definitiva, la prohibición de ir contra acto propio es compatible con la libertad argumentativa de quien representa judicialmente a su cliente en un litigio, porque el derecho de defensa de aquella parte es la contracara del derecho de acción del otro litigante ${ }^{46}$, de modo que -al conectar ambas posiciones: quien demanda con quien es demandado- se hace evidente que el respeto mutuo de sus "expectativas procesales justificadas" 47 los protege por igual de las conductas abusivas ${ }^{48}$. Así como lo señala el Código de Ética, acordado por el Colegio de Abogados de Chile (Santiago de Chile) en 2011, un abogado no puede argumentar en un juicio de un modo tal que implique una "ventaja injustificada" 49.

\section{Los procedimientos laborales}

El intento de fijar los límites de este deber de coherencia acudiendo a categorías mejor delineadas -como la caducidad del plazo, por ejemplo- debe tener en cuenta que, en algunos casos, exigir coherencia a quien litiga puede acarrear secuelas indeseables. Esto último ha ocurrido con frecuencia en la justicia del trabajo, cuando la aplicación de este deber ha llevado a que el trabajador renuncie a derechos que son irrenunciables (art. 5 inciso 2 Código del Trabajo).

En este sentido, por ejemplo, aplicarle este deber de coherencia a un profesor que durante años ha emitido boletas de honorarios y tributado como independiente, cuando deja de prestar tales servicios y demanda por despido injustificado alegando un contrato de trabajo (véase, por todos, Pacareu con Universidad Mayor) ${ }^{50}$, puede afectar la lógica interna del Derecho del trabajo, de acuerdo con la cual dicho profesor tiene derecho a discutir ante un juez la calificación de su desempeño como una situación de subordinación y dependencia, y no como la de un trabajador autónomo que solo arrienda unos servicios inmateriales 51 .

46 TAruffo, M., "General Report. Abuse of Procedural Rights: Comparative Standards of Procedural Fairness", en Abuse of Procedural Rights: Comparative Standards of Procedural Fairness, Michele Taruffo (editor), Kluwer Law International, Hague-London-Boston, 1999, p. 16.

47 GANDulfo, E., "Sobre preclusiones procesales en el derecho chileno en tiempo de reformas. Ensayo de una teoría general desde un enfoque valorativo jurídico”, en Ius et Praxis, 15, No 1, 2009, p. 130.

48 Carretta, F., La coherencia en el proceso civil: Imperativo conductual y decisional desde la buena fe (Casos y jurisprudencia), Thomson Reuters, Santiago de Chile, 2013, p. 92 (cuestiona el papel de la prohibición de ir contra acto propio poniendo en entredicho la existencia de derechos procesales, como el derecho a no sufrir un abuso procesal).

49 Art. 97 Código de Ética: "Límites en la argumentación. El abogado no debe argumentar ante los tribunales de manera dirigida a obtener ventajas injustificadas o de modo que resulte vejatorio para los demás participantes en el juicio. Así, le está prohibido hacer citas de sentencias, leyes u otros textos de autoridad sabiendo o debiendo saber que son inexactas; o aludir a características físicas, sociales, ideológicas u otras análogas respecto de la contraparte o de su abogado, que fueren irrelevantes para la decisión de la controversia".

${ }^{50}$ Corte Suprema, 04 noviembre 2008, Rol No 5.129-2008, cons. $3^{\circ}$. Este caso dio lugar a un proyecto de ley para prohibir "la Teoría del Acto propio" en contra de los derechos de los trabajadores (Boletín N 629413), asumiendo que hay trabajadores que se ven forzados a aceptar contratos simulados.

${ }^{51}$ CaAmaño, E., "Análisis crítico sobre la aplicación de la doctrina de los actos propios en materia laboral”, en Revista de Derecho (Pontificia Universidad Católica de Valparaíso), Vol. 32, 2009, pp. 266-273. 
En un caso como el recién citado, entonces, en vez de limitar la actuación del trabajador mediante la prohibición de ir contra acto propio, el tribunal debe permitir que se litigue al respecto ${ }^{52}$.

Aun así, esto no significa que esta herramienta quede completamente marginada en los procedimientos laborales, ya que el deber de coherencia funciona bien cuando se trata de actuaciones abusivas ${ }^{53}$. Así, en el famoso caso Sternsdorff con Manaplast ${ }^{54}$, la solución judicial fue apropiada en cuanto a no permitir que un gerente de la empresa demandada invocara en su favor la regla que señala que son cláusulas del contrato las que menciona el trabajador (art. 9 Código del Trabajo), porque si el acuerdo no se había escriturado fue porque él mismo, por la posición que ocupaba dentro de la organización de la empresa, no lo hizo.

Este matiz respecto de la prohibición de ir contra acto propio en los procedimientos laborales también es posible hacerlo en otros juicios, como los de consumo y los de arrendamiento, en donde también hay una parte que puede terminar renunciando a derechos que no son renunciables si el deber de coherencia se aplica de forma indiscriminada. En este sentido, cobra relevancia la regla que introdujo la Corte Suprema, en Medina con Garmendia Macus S.A., al pronunciarse sobre un recurso de unificación de jurisprudencia sobre "la validez o ineficacia en la procedencia de la aplicación de la teoría de los actos propios” en los procedimientos laborales. Lo que la Cuarta Sala resolvió entonces fue que no debe "aceptarse la teoría de los actos propios contra los derechos del trabajador, sino solo a su favor, atendida la naturaleza de la relación laboral y la necesaria protección que debe prodigarse al mismo" "55. En otras palabras, este deber de coherencia es un "escudo" del trabajador y no una "espada" del empleador.

La misma regla tendría que aplicarse a quienes litigan en una situación análoga a la del trabajador.

\section{LOS EFECTOS PROCESALES DE IR CONTRA ACTO PROPIO EN LA LITIGACIÓN CIVIL}

A diferencia de los actos jurisdiccionales, cuyo control es posterior a su notificación (ex post), los actos de las partes se controlan de forma previa (ex ante). En este sentido,

\footnotetext{
52 Sierra, A., "La teoría de los actos propios en el ámbito laboral”, en Venire contra factum proprium. Escritos sobre la fundamentación, alcance y límites de la doctrina de los actos propios, Hernán Corral editor, Cuadernos de Extensión, $\mathrm{N}^{\circ} 18,2010$, pp. 141 ss.

${ }^{53}$ López, M., "La teoría de los actos propios en el derecho del trabajo chileno", en Revista Chilena de Derecho, Vol. 43, N², 2016, pp. 361-363.

${ }^{54}$ Corte Suprema, 17 marzo 2003, Rol No 3.236-02, cons. $10^{\circ}$ analizada en ATRIA, F., "Jurisdicción e independencia judicial: el poder judicial como poder nulo", en Revista de Estudios de la Justicia (Universidad de Chile), No 5, 2005, pp. 124-128 (examina el caso como uno de derrotabilidad del art. 9 del Código del Trabajo).

55 Corte Suprema, 12 abril 2018, Rol No 18.304-2016, cons. $5^{\circ}$ (Cuarta Sala: redacción del Abogado Integrante Carlos Pizarro; voto en contra del Abogado Integrante Rodrigo Correa).
} 
la inadmisibilidad de un acto irregular -en un sentido amplio, que incluye al acto que suscita una incoherencia- se diferencia de otras técnicas procesales, como la nulidad, en que aquí el acto no llega a producir efectos ${ }^{56}$.

La inadmisibilidad del acto debe ser, entonces, la respuesta a las actuaciones de parte que violan la prohibición de ir contra acto propio. Esto refuerza el rol preventivo que cumple el juez a la hora de aplicar la buena fe procesal.

En síntesis, la prohibición de ir contra acto propio permite que el juez enfrente la "inestabilidad o falta de coherencia" del comportamiento procesal de algunos litigantes (por todas, Banco Security con Cerva y Ábalos) ${ }^{57}$. Esto se expresa en una cláusula de estilo de la Corte Suprema:

"Los actos propios encuadran el derecho de los litigantes, de forma que no puedan pretender que cuando han reclamado o negado la aplicación de una determinada regla en beneficio propio, puedan aprovechar instrumentalmente la calidad ya negada precedentemente, con perjuicio de los derechos de su contraparte" 58 .

Este control judicial, como se dijo antes, es permanente, de modo que también puede ser ejercido por las Cortes. Por ejemplo, en Burucker con Banco Scotiabank el deudor alegó la simulación del acuerdo como fundamento para demandar, en primera instancia, la nulidad del mutuo hipotecario, mientras que en segunda instancia sostuvo que fue engañado por el banco ejecutante. Para la Corte Suprema, este sutil giro argumentativo no es admisible, porque la simulación se basa en el supuesto engaño padecido, de modo que en ambas instancias se invocó "la misma causa de pedir, toda vez que se arguye sobre la existencia de un engaño que habría afectado la voluntad del actor para celebrar el contrato de mutuo" 59 .

En una situación similar -Banco de Crédito e Inversiones con Palma y otra-, el deudor ejecutado siguió una estrategia diferente, pero orientada al mismo objetivo: solicitó al juez la nulidad de todo lo obrado por un defecto en la notificación y, para el caso de acogerse la nulidad, pidió la prescripción de la deuda respecto de un pagaré con cláusula de aceleración facultativa, por la aceleración del plazo que habría supuesto la demanda ejecutiva cuya nulidad esperaba que se declarase. Al igual que en el caso anterior, la Corte Suprema rechazó esta estrategia aplicando las reglas de la nulidad procesal, de la prescripción y la prohibición de ir contra acto propio ${ }^{60}$.

\footnotetext{
${ }^{56}$ Carrasco, J., "La inadmisibilidad como forma de invalidez de las actuaciones de parte y de terceros técnicos en el Código de Procedimiento Civil”, en Ius et Praxis, Vol. 24. N 1, 2018, p. 516.

${ }^{57}$ Corte Suprema, 02 noviembre 2011, Rol No 5.978-10, VLEX-333766622, cons. $10^{\circ}$ (Primera Sala: redacción del Ministro Sergio Muñoz).

${ }^{58}$ Por todos: Banco del Desarrollo con Vilas, Corte Suprema, 09 octubre 2007, Rol No 2.263-06, VLEX332720062, cons. $6^{\circ}$ (redacción del Abogado Integrante Óscar Herrera).

59 Corte Suprema, 30 julio 2006, Rol No 3.749-04, cons. 9 , LegalPublishing N $^{\circ} 34911$ (redacción del Ministro Jorge Rodríguez).

${ }^{60}$ Corte Suprema, 20 septiembre 2004, Gaceta Jurídica N N $^{\circ}$, cons. $4^{\circ}$ (redacción del Abogado Integrante René Abeliuk).
} 
La prescripción, la caducidad y las reglas de las notificaciones, también sirvieron en Lizana y Homazabal con Banco del Estado de Chile, un caso de responsabilidad civil en donde la prohibición de ir contra acto propio desempeñó nuevamente un papel residual, no secundario. El banco había pagado una indemnización de $\$ 85$ millones, como tercero civilmente responsable, por los perjuicios derivados de un accidente de tránsito, a víctimas que interpusieron una nueva demanda en su contra pidiendo $\$ 340$ millones por daño moral (debido a la muerte de un hijo y del estado semiparapléjico en que quedó uno de los sobrevivientes, padre de dos hijos). En primera instancia, el fallo acogió la excepción de prescripción del banco demandado, pero la actora apeló porque, en su opinión, el banco se habría notificado tácitamente de esta nueva demanda, ya que al haber pedido la nulidad de la notificación de la demanda habría operado el art. 55 inciso $2^{\circ} \mathrm{CPC}^{61}$. Esta estrategia no tuvo éxito ante la Corte de La Serena, la que consideró que se contradecía una omisión propia, ya que la demandante no impugnó el fallo de primera instancia que rechazó el emplazamiento por notificación tácita y que ordenó, en cambio, la notificación al banco mediante exhorto; por tanto, su argumento en el nuevo juicio iba "contra sus comportamientos pretéritos, lo que no puede aceptarse sin contravenir gravemente al principio de la buena fe" 62 .

Por tanto, sea o no con el apoyo de otras categorías procesales, la prohibición de ir contra acto propio tiene un efecto procesal específico: la inadmisibilidad del acto incoherente. Lo que resta por ver es si este efecto es compatible con otras medidas que desincentivan estrategias de litigación que infringen la buena fe procesal.

\section{Las costas procesales y la indemnización de los perjuicios}

A raíz de la regulación mediante auto acordado que la Corte Suprema hizo de las costas que se pagan en las protecciones en contra de empresas aseguradoras de servicios médicos, el Tribunal Constitucional sostuvo que "las costas no son sanciones propiamente tales, sino consecuencias jurídicas derivadas del incumplimiento de cargas procesales [de modo que] se trata, entonces, del reembolso de gastos originados en el proceso por la misma parte, y no de una multa o sanción pecuniaria" ${ }^{63}$. Si bien esta premisa es polémica, ya que las costas tienen una dimensión sancionatoria y proceden no solo por el incumplimiento de cargas, lo que ahora interesa destacar es lo que el Tribunal Constitucional concluyó a partir de ella:

61 Art. 55 inciso 2 Código de Procedimiento Civil: “Asimismo, la parte que solicitó la nulidad de una notificación, por el solo ministerio de la ley, se tendrá por notificada de la resolución cuya notificación fue declarada nula, desde que se le notifique la sentencia que declara tal nulidad. En caso que la nulidad de la notificación haya sido declarada por un tribunal superior, esta notificación se tendrá por efectuada al notificársele el "cúmplase" de dicha resolución".

${ }^{62}$ Corte de Apelaciones de La Serena, 27 abril 2004, Rol No 29.688-03, cons. 2 ${ }^{\circ}$, LegalPublishing No 32041 (redacción del Abogado Integrante Leonel Rodríguez).

63 Tribunal Constitucional, 14 abril 2011, Rol No $1.557-2011$, cons. $27^{\circ}$. 
"Cualquier litigante que interpone una acción o una defensa, desde su primera actuación en el juicio, está consciente de que, dependiendo del desarrollo del procedimiento, puede quedar en evidencia un actuar negligente o carente de plausibilidad que lo haga acreedor a la condena en costas en la sentencia definitiva. Es en la perspectiva indicada que se cumple con los estándares de racionalidad y justicia del procedimiento" (cons. $28^{\circ}$ ).

Como se puede ver, el pago de las costas es compatible con el debido proceso cuando dicha obligación se impone a quien litiga de un modo "negligente" o, al menos "carente de plausibilidad". Como se ha visto, el deber de coherencia dispone que no es admisible o atendible que una parte contradiga su conducta previa, defraudando las expectativas legítimas de la contraparte, con el propósito de lograr una posición ventajosa en el juicio.

Una cuestión diferente, en tanto, es si también se puede obligar a indemnizar los perjuicios que provoca quien litiga sin plausibilidad, entendiendo dentro de esta categoría a las conductas incoherentes. Para discutir este último punto es sumamente elocuente revisar el caso Opazo y otro con Brown y otra ${ }^{64}$. La historia aquí fue la siguiente: en un campo de la zona central de Chile, al morir un hombre, sus dos hermanos -una mujer y un hombre- demandaron a la viuda y al hijo del difunto, con el fin de impugnar la filiación biológica de su sobrino, quien no sería hijo de la viuda. Lo que este hijo no sabría es que treinta años atrás, la viuda y la madre biológica viajaron a Santiago y simularon el parto, con el acuerdo del difunto, padre biológico del recién nacido.

Desde el punto de vista del Derecho de familia quienes impugnaron la filiación no tenían legitimación activa para ello, porque solo puede impugnar la filiación aquella persona a quien la maternidad aparente perjudique actualmente en sus derechos sobre la sucesión del supuesto padre o madre, y siempre que no se establezca la posesión notoria del estado civil de hijo (art. 218 CC). Ninguno de estos requisitos concurría en los hechos -los hermanos del difunto no tenían derecho en la sucesión del causante y el hijo poseía el estado civil de tal en forma notoria-, de modo que la demanda fue rechazada. La cuestión de la infracción a la buena fe procesal y la posibilidad de demandar la indemnización de los perjuicios surgió después del fallo.

En efecto, concluido el juicio de filiación, la madre, entonces de ochenta y un años, junto con su hijo, interpusieron una demanda civil de indemnización de daños en contra de los dos hermanos del causante, por ejercicio abusivo de la acción de impugnación de filiación. Los hermanos habrían actuado de mala fe al demandar a su cuñada y sobrino sin tener derechos sobre la herencia de su hermano, ya que serían la cónyuge sobreviviente y el hijo biológico quienes lo heredarían (art. 989 CC) ${ }^{65}$.

${ }^{64}$ Juzgado de Letras de San Vicente de Tagua Tagua, 22 mayo 2007, Rol N 43.829 , cons. 16 ${ }^{\circ}$, LegalPublishing No 42866 (redacción de la Jueza Carolina Garrido) analizada en Walker, N., "Daños causados por divulgación de la verdad”, en Revista Chilena de Derecho y Ciencia Política (Universidad Católica de Temuco), Vol. 2, N² 2, 2011, pp. 211 ss.

${ }^{65}$ Esta demanda pretendió recuperar, como daño patrimonial, los honorarios del abogado que pagaron la madre y su hijo en el juicio de filiación (\$3.000.000) y compensar el daño moral sufrido, el que se estimó en $\$ 200.000 .000$. 
En este segundo juicio -el de responsabilidad civil- el Juzgado de Letras de San Vicente de Tagua Tagua acogió la demanda, pronunciándose sobre el margen de tolerancia que admite la argumentación jurídica en la litigación civil:

"En el caso de autos, esta sentenciadora estima que tal límite de tolerancia ha sido sobrepasado, pues la acción de filiación interpuesta, solo pudo tener por objeto el ánimo de perjudicar a los demandados y no el ánimo de obtener lo solicitado en la demanda, pues tal y como se señaló en las sentencias definitivas de primera y segunda instancia, los demandantes ni siquiera se encontraban legitimados activamente para ejercer la acción interpuesta y actuaron además invocando disposiciones legales inexistentes a la fecha de interposición de la demanda, incurriendo en consecuencia en un error de derecho que resulta por su magnitud inexcusable, el cual además, según lo dispone el artículo 706 del Código Civil, constituye una presunción de mala fe que no admite prueba en contrario" (cons. 16 $6^{\circ}$.

La Corte de Rancagua, en tanto, confirmó este fallo (cons. $4^{\circ}$ ), agregando que la mala fe en la litigación de los hermanos se demuestra, no solo porque su demanda "se fundó en disposiciones legales derogadas”, sino que, además, por el hecho de que la demanda de impugnación se presentó transcurridos apenas tres meses de la muerte del padre, lo que "denota un espíritu dañoso, sin que resulte verosímil la circunstancia de que los demandados supieron el mismo día de la defunción del padre” que su sobrino no era hijo biológico de la viuda ${ }^{66}$. Para la Corte de Rancagua la demanda de impugnación de filiación no solo fue "abusiva, sino que además incomprensible, innecesaria, irreflexiva y antojadiza” (cons. $6^{\circ}$ ), por lo que no acogió la defensa de los demandados en cuanto a que todos los hechos que narraron en su demanda de impugnación eran, a fin de cuentas, verdaderos ${ }^{67}$.

Finalmente, la Corte Suprema compartió la decisión de la Corte de Rancagua -que enfatizó la "prudencia procesal” y "una mínima precaución” al demandar-, porque "ha quedado en evidencia que los actores del juicio de filiación desatendieron reglas

${ }^{66}$ Corte de Apelaciones de Rancagua, $1^{\circ}$ abril 2008, Rol No 592-2007, cons. $4^{\circ}$, LegalPublishing No 42866 (redacción del Ministro Miguel Vásquez) ("a ello hay que agregar la osadía de deducir una demanda con acciones manifiestamente prescritas, lo que atenta contra toda prudencia procesal, pues si bien es efectivo que la prescripción puede ser renunciada, al no alegarla, lo cierto es que una mínima precaución aconsejaba no presentarla, salvo que, como necesariamente ha de presumirse, la intención de los demandantes no está en perseguir el éxito de la demanda, sino que dar a conocer, por escrito, una situación de hecho, que necesariamente, iba a provocar en los destinatarios un impacto emocional muy fuerte").

${ }^{67}$ Sobre este punto, en particular, la Corte de Rancagua señaló lo siguiente: "Si ellos [los hermanos que demandaron] pretendían hacer saber una verdad cabe preguntarse ¿por qué razón no se lo informaron directamente, sin necesidad de recurrir a la instancia judicial? Tal interrogante no tiene respuesta con los datos proporcionados por los demandados en el presente juicio, ni en el que perdieron. Si bien es efectivo que la verdad en sí misma es un bien superior, condición loable en toda persona, lo es cierto que su revelación en determinadas circunstancias puede ser fuente de obligaciones. Ello acontecerá cuando aquella revelación cause un daño injustificado a quien se ve impactado con el conocimiento de la misma y que el contarla no obedece a obligación alguna" (cons. $5^{\circ}$ ). 
categóricas de legitimación activa para demandar, prescindiendo de disposiciones legales ampliamente conocidas desde la reforma introducida por la Ley 19.585 (D.O. 26 de octubre de 1998)"68. Para la Corte Suprema:

"Los hechos fácticos [sic] demuestran ineludiblemente que hubo mala fe en el ejercicio de la acción de filiación, al haberse basado en derechos hereditarios inexistentes, ignorando manifiestamente y sin justificaciones razonables las transformaciones elementales de las disciplinas jurídicas del derecho de familia y derecho sucesorio. Representa un caso en que la acción es utilizada con un fin dañoso y como una herramienta ilícita de presión" (cons. 10).

En definitiva, el estándar de Opazo para que se indemnicen los daños que causa una actuación procesal incoherente, por cuanto carece de plausibilidad y traspasa el "límite de tolerancia" argumentativa es, como se puede apreciar, bastante exigente, ya que se debe probar el dolo directo.

En la litigación civil patrimonial, en tanto, rige el mismo estándar. Así quedó establecido en el caso líder al respecto, Inmobiliaria Nacional Ltda. con Centrobanco, resuelto en 1992 .

En Inmobiliaria Nacional Ltda., el demandado de responsabilidad civil extracontractual había promovido, en un anterior juicio ejecutivo hipotecario en que actuó como ejecutante, dos incidentes de nulidad procesal para dejar sin efecto el remate de la finca hipotecada, la que luego sería adjudicada a quien ahora demandaba los daños. Dichos incidentes fueron rechazados tras una extensa tramitación.

La Corte de Santiago consideró que tales incidentes "solo tuvieron por objeto causar un perjuicio a los subastadores sin que los incidentistas tuvieran una causa o interés legítimos para deducirlos" 69 , vulnerando con ello la buena fe procesal, la que "exige a los contendientes una actuación leal en el uso de pretensiones, defensas o recursos, sancionándose cualquier exceso en el uso de expedientes dilatorios o pretensiones infundadas" (cons. $5^{\circ}$ ). Al igual que en Opazo, la Corte de Santiago concluyó que se debe probar un dolo directo para indemnizar los daños causados, esto es, "debe existir un ánimo manifiesto de perjudicar o una evidente falta de interés o necesidad de lo que promueva o un actuar motivado por el afán de causar un perjuicio a su contraparte o co-contratante" (cons. $\left.4^{\circ}\right)^{70}$.

${ }^{68}$ Corte Suprema, 24 noviembre 2009, Rol N $2.275-2008$, cons. $8^{\circ}$, LegalPublishing N $^{\circ} 42866$ (redacción de la Ministra Sonia Araneda).

${ }^{69}$ Corte de Apelaciones de Santiago, 09 noviembre 1992, Rol N ${ }^{\circ} 1.330-90$, cons. $3^{\circ}$, LegalPublishing $\mathrm{N}^{\circ} 20074$ (redacción del Ministro Milton Juica) ("hay que considerar, todos los hechos que rodearon la ejecución misma y que el fallo de primer grado deja establecidos en los considerandos tercero y noveno todo lo cual evidencia, tanto de parte de los ejecutados de que el juicio, como de los terceristas que advinieron un afán de perjudicar al acreedor, al nivel de privarlo no sólo su crédito sino también de la hipoteca que garantizaba dicha acreencia").

${ }^{70}$ En el caso concreto la Corte de Santiago rechazó la demanda de indemnización de daños al estimar que el actor no logró probar el dolo en la actuación del ejecutado: "La circunstancia de que dichos incidentes, 


\section{CONCLUSiOnes}

La prohibición de ir contra acto propio es un caso típico de infracción al principio de buena fe procesal. Esta prohibición da cuenta de un deber de coherencia que los litigantes tienen que respetar en los procedimientos judiciales civiles. Este deber busca garantizar que las estrategias de litigación no defrauden las expectativas normativas de una parte, basadas en el comportamiento - sean acciones u omisiones- que la contraria ha tenido, ya sea en el mismo juicio o en litigios previos que se relacionan con este.

Esta prohibición, por tanto, da cuenta de una tensión entre la coherencia exigible a los litigantes y el derecho de defensa que les garantiza el texto constitucional.

Este artículo ha examinado las dos interpretaciones - una amplia y otra restringidaque la jurisprudencia civil reconoce cuando aplica este deber de coherencia. Su versión amplia no solo modula el derecho de defensa de las partes, sino que incluso puede afectar el acceso a la justicia, cancelando facultades que la propia ley les reconoce a los litigantes, como la acumulación de pretensiones incompatibles en la demanda. Esta tesis liga al deber de coherencia con la prejudicialidad y permite cubrir situaciones que la excepción de cosa juzgada no alcanza a evitar.

La aplicación restringida, en tanto, entiende esta prohibición como un control judicial permanente de la argumentación jurídica para resguardar el derecho de los litigantes a no verse afectados por conductas abusivas, fraudulentas o manifiestamente dilatorias.

La protección de la confianza legítima que suscitan las actuaciones procesales tiene matices, según sea el procedimiento de que se trate. Así, por ejemplo, en el caso de la justicia del trabajo la prohibición de ir contra acto propio solo podría favorecer los intereses del trabajador, no los del empleador. Esta interpretación podría aplicarse, por analogía, a otros juicios estructuralmente similares.

El texto distinguió entre una aplicación secundaria (obiter dicta) y una aplicación residual de este deber. Esta distinción es importante porque, en la motivación de los fallos, este deber de coherencia suele ir acompañado de otras categorías procesales mejor delineadas en la cultura jurídica interna, aunque también puede serlo con figuras cuya formalización aún es igualmente difusa, como la protección de la apariencia (cuando la incoherencia descansa en una sola conducta previa, incluso cuando ella es una omisión) o el levantamiento del velo (como ha ocurrido en los casos de simulación). Esta aplicación secundaria es conceptualmente diversa de su aplicación residual, en donde la jueza o juez cumple una tarea preventiva en cuanto a evitar que se tomen decisiones que vulneran la buena fe procesal.

cuya duración pudo ser excesiva, lo que no puede imputarse únicamente al incidentista dentro de la relación procesal, se hubiesen rechazado, significa solo que falló la pretensión aun cuando se hubiese fundado el rechazo en la falta de legitimación para accionar, esta decisión no puede significar que al momento de la interposición de los artículos, estos carecían de interés, ya que de sus propios fundamentos se desprende que los hubo; había una pretensión de relevancia jurídica para justificar la nulidad impetrada, ya que con ella se pretendía una nueva licitación de la propiedad hipotecada, con resguardo evidente de los intereses económicos del banco acreedor" (cons. $6^{\circ}$ ). 
El efecto de infringir este deber de coherencia es la inadmisibilidad del acto incoherente. Esta consecuencia procesal es compatible con otras medidas específicas que pueden ordenarse para disuadir las estrategias de litigación que buscan obtener ventajas injustificadas, como el pago de las costas -cuando se trata de actuaciones que no son plausibles o tolerables- y la indemnización de los daños causados, la que tiene que determinarse en un juicio declarativo posterior y exige probar que el litigante actuó con dolo directo.

\section{BIBLIOGRAFÍA}

Atria, F., 2005: “Jurisdicción e independencia judicial: el poder judicial como poder nulo”, en Revista de Estudios de la Justicia (Universidad de Chile), No 5, pp. 119-141.

Bertea, S., 2005: "The Arguments from Coherence: Analysis and Evaluation”, en Oxford Journal of Legal Studies, 25, No 3, pp. 369-391.

Bone, R., 2013: "Procedure, Participation, Rights”, en Boston University Law Review, 90, 2010, pp. 1011-1028 ["Procedimiento, participación, derechos", en Derecho procesal civil comparado: Homenaje a Rolf Stürner, Álvaro Pérez Ragone y Pía Tavolari Goycoolea (coordinadores), Thomson Reuters, Santiago de Chile, pp. 223-248].

CaAmaño, E., 2009: "Análisis crítico sobre la aplicación de la doctrina de los actos propios en materia laboral”, en Revista de Derecho (Pontificia Universidad Católica de Valparaíso), Vol. 32, pp. 261-280.

Carrasco, N., 2017: "El proceso civil como juego no repetitivo y como vía para interiorizar cargar informativas: Una mirada desde el análisis económico del derecho”, en Revista Chilena de Derecho, Vol. 44, $\mathrm{N}^{\circ} 1$, pp. 185-208.

Carrasco, J., 2018: "La inadmisibilidad como forma de invalidez de las actuaciones de parte y de terceros técnicos en el Código de Procedimiento Civil”, en Ius et Praxis, Vol. 24. No 1 , pp. 497-552.

Carretta, F., 2018: “¿Los actos propios en el proceso civil? A propósito del principio de la buena fe procesal y su incorporación en la Ley 20.886 sobre Tramitación Electrónica en el procedimiento civil chileno", en Revista de Derecho Privado (Universidad Externado de Colombia), $\mathrm{N}^{\circ}$ 35, pp. 327-347.

CARRETTA, F., 2013: La coherencia en el proceso civil: Imperativo conductual y decisional desde la buena fe (Casos y jurisprudencia), Thomson Reuters, Santiago de Chile, 350 pp.

Carretta, F., 2008: "Deberes procesales de las partes en el proceso civil chileno", en Revista de Derecho (Universidad Austral), Vol. 21, No 1, pp. 101-127.

Contardo, J. I., 2010: "La doctrina de los actos propios en la jurisprudencia civil chilena", en Venire contra factum proprium. Escritos sobre la fundamentación, alcance y límites de la doctrina de los actos propios, Hernán Corral editor, Cuadernos de Extensión, No 18, pp. 81-102.

Corral, H., 2010: "La doctrina de los actos propios en el derecho de familia chileno", en Venire contra factum proprium. Escritos sobre la fundamentación, alcance y límites de la doctrina de los actos propios, Hernán Corral editor, Cuadernos de Extensión, Nº 18, pp 103-139.

Dougnac, F., 2001: "Reflexiones sobre la acción de protección y su sentencia", en Revista Chilena de Derecho, Vol. 28, $\mathrm{N}^{\circ} 3$, pp. 615-630.

GANDUlfo, E., 2009: "Sobre preclusiones procesales en el derecho chileno en tiempo de reformas. Ensayo de una teoría general desde un enfoque valorativo jurídico", en Ius et Praxis, $15, \mathrm{~N}^{\circ} 1$, pp. 121-189. 
GANDULFO, E., 2005: "La aplicación del principio venire contra factum proprium non valet. Un caso de vulgarismo jurídico", en Revista Chilena de Derecho, Vol. 32, No 2, pp. 363-374.

Hunter, I., 2008: "No hay buena fe sin interés: La buena fe procesal y los deberes de veracidad, completitud y colaboración”, en Revista de Derecho (Universidad Austral), Vol. 21, N², pp. 151-182.

Larroucau, J. y Rostión, I., 2013: "Del juicio de precario", en Fundamento de derechos reales en el derecho chileno, Rodrigo Barcia Lehmann compilador, Thomson Reuters, Santiago de Chile, pp. 37-105.

Larroucau, J., 2017: "Adiós a las fojas. Reglas procesales, autos acordados y tramitación electrónica en Chile”, en Revista de Derecho Privado (Universidad Externado de Colombia), $\mathrm{N}^{\circ} 33$, pp. 195-234.

Larroucau, J., 2015: “Demandas abusivas”, en La buena fe en la jurisprudencia: comentarios y análisis de sentencias, Lilian San Martín (editora), Silvia Retamales y Valentina Guevara (coordinadoras), Thomson Reuters, Santiago de Chile, pp. 51-61.

Larroucau, J., 2013: "Tres lecturas de la buena fe procesal", en Revista Chilena de Derecho Privado, No 21 , pp. 259-305.

Larroucau, J., 2012: “La opción de responsabilidad civil como un acertijo procesal”, en Estudios de Derecho Civil VII, Fabián Elorriaga coordinador, Thomson Reuters, Santiago de Chile, pp. 461-479.

López, M., 2016: "La teoría de los actos propios en el derecho del trabajo chileno", en Revista Chilena de Derecho, Vol. 43, No 2, pp. 549-573.

Morales, M. E., 2014: "La prohibición de ir contra acto propio como manifestación de la exigencia al consumidor de actuar conforme a los parámetros de la buena fe (Corte de Apelaciones de Santiago)", en Revista de Derecho (Universidad Austral), Vol. 27, № 1, pp. 247-251.

Padilla, R., 2013: "Por una correcta aplicación de la doctrina de los actos propios", en Revista Chilena de Derecho Privado, No 20, pp. 135-183.

PÉreZ, M. F., 2014: "La protección del dueño ante quien retiene indebidamente un bien. Análisis jurisprudencial del artículo 915 del Código de Bello", en Revista de Derecho (Universidad Católica del Norte), 21, No 1, pp. 387-421.

Picó i Junoy, J., 2006: "El debido proceso 'leal'. Reflexiones en torno al fundamento constitucional del principio de la buena fe procesal", en Revista Peruana de Derecho Procesal, Vol. 9, pp. 331-372.

Romero, A., 2010: "El acto propio en materia arbitral: Algunos límites probatorios para su aplicación”, en Venire contra factum proprium. Escritos sobre la fundamentación, alcance y límites de la doctrina de los actos propios, Hernán Corral editor, Cuadernos de Extensión, No 18, pp. 69-79.

Romero, A., 2003: "El principio de buena fe procesal y su desarrollo en la jurisprudencia, a la luz de la doctrina de los actos propios", en Revista Chilena de Derecho, Vol. 30, No 1, pp. 167-172.

Sierra, A., 2010: "La teoría de los actos propios en el ámbito laboral", en Venire contra factum proprium. Escritos sobre la fundamentación, alcance y limites de la doctrina de los actos propios, Hernán Corral editor, Cuadernos de Extensión, Nº 18, pp. 141-151.

TAruffo, M., 1999: "General Report. Abuse of Procedural Rights: Comparative Standards of Procedural Fairness", en Abuse of Procedural Rights: Comparative Standards of Procedural Fairness, Michele Taruffo (editor), Kluwer Law International, Hague-London-Boston.

TAvolari, R., 1996: "De la aceleración, la interrupción de la prescripción y la doctrina de los actos propios en el proceso", en Gaceta Jurídica N $\mathrm{N}^{\circ} 188$, pp. 88-102.

TwinInG, W., 2006: Rethinking Evidence. Exploratory Essays, Cambridge University Press, $2^{\text {a }}$ Edición, 511 pp. 
VÁsquez, M. F., 2010: "Revisión de la competencia del árbitro en relación al tiempo y la materia”, en Ius et Praxis, Vol. 16, No 2, pp. 443-460.

Walker, N., 2011: "Daños causados por divulgación de la verdad", en Revista Chilena de Derecho y Ciencia Política (Universidad Católica de Temuco), Vol. 2, No 2, pp. 211-226.

Zeiss, W., 1979 (1967): El dolo procesal. Aporte a la precisación teórica de una probibición del dolo en el proceso de cognición civilístico, traducción de Tomas Banzhaf, Ediciones Jurídicas EuropaAmérica, Buenos Aires, 256 pp. 